SORIN RADU

Uniwersytet Luciana Blagi, Sybin, Rumunia

FLAVIUS SOLOMON

Rumuńska Akademia, Instytut Historii

Aleksandru D. Xenopola, Jassy, Rumunia

\title{
CHŁOPSKIE ORGANIZACJE POLITYCZNE W KOMUNISTYCZNEJ RUMUNII: CASUS FRONTU ORACZY (1945-1953)*
}

Front Oraczy (rum. Frontul Plugarilor) był organizacją polityczną założoną przez grupę chłopów z okręgu Hunedoara, z Petru Grozą na czele, której zamiarem była ochrona interesów gospodarczych i politycznych mieszkańców wsi, poprzez walkę z politykami i partiami politycznymi. W krótkim czasie od swojego założenia FO stał się jedną z najbardziej posłusznych wobec Rumuńskiej Partii Komunistycznej (rum. Partidul Comunist Român, PCR) organizacji politycznych, ta cecha zaś szczególnie uwydatniła się w okresie powojennym. W kontekście politycznym po II wojnie światowej organizacja ta - nie licząca się w latach trzydziestych - odegra ważną rolę w budowie „nowego świata” (według wyrażenia P. Grozy), wchodząc w orbitę partii komunistycznej. Komuniści przyczynili się do sztucznego rozwoju organizacji oraczy, ze szczególnym zamiarem zaatakowania Partii Narodowo-Chłopskiej w środowiskach wiejskich (najważniejszej partii politycznej w Rumunii po roku 1945), ale także w celu rozpowszechniania idei komunistycznych wśród chłopów.

Niniejszy artykuł ma za zadanie przedstawić działalność partii, a przede wszystkim sposób, w jaki PCR zaangażowała się w rozwój organizacyjny FO, postrzeganego jako polityczny organ chłopstwa, w celu pozyskania dla komunizmu rumuńskich środowisk wiejskich. Badania

* Powyższa praca powstała dzięki wsparciu CNCS-UEFISCDI, projekt nr PN-II-RU-TE-2012-3-0334 - Komunizm na wsi rumuńskiej. Studium przypadku: Propaganda Frontu Oraczy (1944-1953). W skróconej formie została zaprezentowana na „Rural History Conference 2013" zorganizowanej przez European Rural History Organisation (EURHO), na Uniwersytecie Berneńskim, 19-22 sierpnia 2013 r. 
oparte zostały na ocenie niepublikowanych dotąd źródeł archiwalnych, historiografii rumuńskiej i zagranicznej, jak również publikacjach propagandowych FO.

\section{Początki Frontu Oraczy}

W Dewie 8 stycznia 1933 r. miało miejsce pierwsze wystąpienie publiczne, podczas którego adwokat dr Groza ${ }^{1}$ wyróżnił się jako niepodważalny lider nowej organizacji. Groza był jednym z najbogatszych mieszkańców Rumunii i byłym członkiem licznych partii, znanym ze swoich związków z komunistami, działającymi wówczas poza prawem. Program FO opublikowany 18 kwietnia 1933 r. pod tytułem „Nasze credo” (Crezul nostru) zawierał siedemnaście artykułów. Argumentacja i użyta w nim terminologia prawnicza wskazywały na to, że dokument nie był dziełem chłopów, lecz raczej ludzi oswojonych ze słownictwem ekonomicznym i prawniczym. Ostatni artykuł w programie podkreślał, że Front reprezentuje interesy wszystkich chłopów, niezależnie od ich języka, pochodzenia i wyznania. W zgromadzeniu założycielskim FO uczestniczyło, zgodnie z szacunkami jego liderów, około 12 tys. chłopów, głównie z okręgu Hunedoara, ale także z okręgów sąsiednich².

FO wystawił swoje listy wyborcze na poziomie okręgu Hunedoara w wyborach z 1933, jak i 1937 r., z rozczarowującymi rezultatami - poniżej progu wyborczego, wynoszącego $2 \%^{3}$. Po wprowadzeniu w Rumunii przez króla Karola II ustroju monarchii autorytarnej (w lutym 1938) i wydaniu Dekretu z 30 marca 1938 r., który zakazywał działalności partii i organizacji politycznych, liderzy FO, podobnie jak i liderzy innych partii, nie zawiesili swojej działalności i kontynuowali spotkania oraz utrzymywali łączność z organizacjami na poziomie gmin i wsi.

Po przystąpieniu Rumunii do II wojny światowej Groza wykazał się wyjątkową aktywnością polityczną. Przedstawiciele reżimu Iona Antonescu wydawali się zaniepokojeni agitacją prowadzoną przez lidera FO, czego dowodem są liczne sprawozdania i notatki Biura Bezpieczeństwa oraz Policji (Biroul de Siguranță și Poliție - w strukturze Ministerstwa Spraw Wewnętrznych). Groza odbywał ponadto częste spotkania z działaczami komunistycznymi w Klużu, znajdującym się po arbitrażu pod rządami węgierskimi. Dyskusje z nimi, jak również rozwój działań wojennych utrwali-

${ }^{1}$ Biografia P. Grozy - zob. D. Liviu-Bîtfoi, Petru Groza, ultimul Burghez. O biografie, București, 2004. Nie zawiera analizy działalności FO.

${ }^{2}$ Ce vrem? Istoricul. Programul. Organizarea, Deva 1933, passim.

${ }^{3}$ A. Nistor, Poziția forțelor democratice hunedorene în alegerile parlamentare din decembrie 1937, „Sargeția”, R. 14, 1979, s. 503-505. 
ły w nim przekonanie, że socjalizm jest jedynym ratunkiem dla ludzkości. Prokomunistycznego nastawienia Grozy dowodzi także jego zaangażowanie w tworzenie Patriotycznego Frontu Antyhitlerowskiego (rum. Frontul Patriotic Antihitlerist) jesienią roku 1943. W skład tego sojuszu, zawiązanego z inicjatywy partii komunistycznej, weszły PCR, FO, Związek Patriotów - ugrupowanie socjalistyczno-chłopskie, któremu przewodniczył Mihail Ralea oraz MADOSZ - Związek Węgierskich Robotników w Rumunii. Platforma programowa tej koalicji została ogłoszona przez komunistów w czerwcu 1943 r., niedługo po rozwiązaniu Kominternu4. Efektem działalności konspiracyjnej było śledztwo, aresztowanie i uwięzienie na niemal dwa miesiące głównych działaczy FO: Petru Grozy, Georghe Miclego oraz Mirona Belei. Czas spędzony w więzieniu Groza wykorzystał na przemyślenia, których efektem była publikacja În umbra celulei. Malmaison, 1943-1944 iarna ${ }^{5}$ (W cieniu celi. Malmaison, zima 1943-1944). Został zwolniony pod koniec stycznia $1944 \mathrm{r}$.

\section{Przekształcenie Frontu Oraczy w organizację masową}

Po 23 sierpnia 1944 r., kiedy to od władzy został odsunięty marszałek I. Antonescu, FO został ponownie zalegalizowany i natychmiast zajął się odbudową struktur w okręgu Hunedoara oraz rozszerzeniem akcji propagandowych na sąsiednie okręgi. W tym celu, we współpracy z partią komunistyczną, Związkiem Patriotów, Patriotyczną Obroną (Apărarea Patriotică) i MADOSZ, FO przystąpił 29 września 1944 r. do Frontu Narodowo-Demokratycznego (rum. Frontul Național Democrat - FND) - sojuszu politycznego kontrolowanego przez komunistów. Deklarowanym celem tej formacji politycznej była „organizacja ogromnej energii, pochodzącej od sektora rolniczego kraju" ". Przystąpienie do FND stanowiło moment zwrotny, od którego rozpoczęła się droga FO, czy raczej wąskiej elity jego przywódców, na wyżyny władzy politycznej. Pierwszym krokiem na tej drodze było mianowanie Grozy wicepremierem drugiego rządu generała Constantina Sănătescu, 4 listopada 1944 r. Rola FO zaczęła znacznie się wzmacniać wraz z powołaniem, na wyraźne żądanie władz radzieckich, rządu Grozy 6 marca 1945 r. Wtedy to Front, cieszący się pełnym wsparciem logistycznym aparatu państwowego, stał się biegunem

\footnotetext{
${ }^{4}$ N. Georgescu, Frontul Plugarilor în anii 1938-1944, „Anuarul Institutului de Cercetări Socio-Umane Sibiu", vol. 16, 2009, s. 23-33.

${ }^{5}$ P. Groza, În umbra celulei. Malmaison, 1943-1944 iarna, București 1945.

${ }^{6}$ „să organizeze energiile imense din sectorul agrar al țării”, G. Micle, Frontul Plugarilor, Cum s-a născut? Ce este? Ce vrea?, Sibiu 1944, s. 46-48.
} 
przyciągającym masy ludowe. Lider FO był w oczach Stalina najodpowiedniejszym rumuńskim politykiem do kierowania rządem przejściowym. Rząd ten był zdominowany przez komunistów, lojalny wobec ZSRR, lecz - na użytek Brytyjczyków i Amerykanów - miał sprawiać wrażenie formalnie demokratycznego i wielopartyjnego. W skład tego rządu weszli także i inni działacze FO: M. Ralea - Ministerstwo Sztuk, Romulus Zăroni - w Departamencie Rolnictwa i Zasobów Rolnych, Constantin Agiu zaś został podsekretarzem stanu w tym samym ministerstwie?

Od tego momentu FO zaczął gwałtownie się zmieniać pod uważnym nadzorem PCR. W bardzo krótkim czasie ugrupowanie to, działające dotąd przede wszystkim w okręgu Hunedoara i skromnie reprezentowane w kilku innych okręgach, utworzyło ogólnokrajowe struktury i zaczęło odgrywać ważną rolę w grze politycznej, mającej na celu przejęcie władzy przez komunistów. Na podstawie wiarygodnych źródeł można oszacować, że w latach 1948-1949 FO miał ok. 1,4-1,5 mln członków, to jest wielokrotnie więcej niż partia komunistyczna.

Ekspansja organizacyjna FO w latach 1944-1947 odbyła się przy udziale i bezpośredniej pomocy PCR. Oba ugrupowania do współpracy motywował wspólny cel; kooperacja ta sięgała zresztą połowy lat trzydziestych. Wyobrażenia dotyczące przyszłości tej współpracy były jednak zgoła inne: liderzy komunistyczni uważali FO za przedłużenie własnej partii w środowiskach wiejskich, za organizację komunistyczną, stworzoną w celu przyciągnięcia mas chłopskich, dla osłabienia wpływów Partii Narodowo-Chłopskiej (Partidul Național-Țărănesc, PNȚ) i stopniowego przejmowania władzy oraz przygotowania terenu do komunizacji społeczeństwa. Nikła popularność komunistów na wsi oraz jasne sygnały, które potwierdzały tę tezę, sprawiały, że działacze komunistyczni ukrywali te intencje oraz związki, które łączyły ich z Oraczami. Stąd ich strategia „wysyłania do pracy” do FO zaufanych komunistów, ludzi ze zdolnościami organizacyjnymi, którzy mieli wspomagać Front i kontrolować, by jego członkowie „trzymali słuszny kierunek”. Mieli przy tym dbać, by nie zdradzić jednocześnie swej podwójnej tożsamości politycznej. Fenomen ten był widoczny zarówno w strukturach centralnych, jak i lokalnych FO. Dla partii komunistycznej rozwój FO, zdobywanie przezeń jak najwięcej członków, był głównym celem w ramach generalnego planu zdobywania władzy. Taktyka ta była zatwierdzona przez samego Grozę ${ }^{8}$.

${ }^{7}$ N. Georgescu, S. Radu, Refacerea politică și extinderea organizatorică a Frontului Plugarilor în anii 1944-1945, „Studia Universitatis Petru Maior”, Historia, nr 9, 2009 , s. $198-214$.

${ }^{8}$ Serviciul Județean Timiș al Arhivelor Naționale ale României SJTANR [Oddział 
Starsi liderzy FO - tak zwana „grupa z Dewy” - mieli jednak inny pogląd na stosunki z PCR. Byli w większości prostymi ludźmi, oraczami w prawdziwym znaczeniu tego słowa, ludźmi pełnymi poświęcenia i dumy z własnych, choć drobnych, dokonań politycznych w okręgu Hunedoara. Uważali, że Front powinien obrać własną drogę polityczną i posiadać własną misję: reprezentacji politycznej i podnoszenia statusu społecznego chłopów. FO należał do nich, to oni założyli tę organizację i sprzeciwiali się próbom zawłaszczenia jej przez komunistów. Sojusz z klasą robotniczą, z partią komunistyczną rozumieli całkowicie inaczej: PCR miała pomóc rozwinąć Front (przez granie roli „bardziej oświeconego oddziału" ruchu robotniczego), ale bez prób ingerencji w kierowanie organizacją i, przede wszystkim, bez zmieniania jej celów politycznych. Do tzw. „Grupy Zăroni-Belea” zaliczał się także profesor Mihail Ghelmegeanu, stary ideolog narodowo-chłopski, który widział rolę FO w perspektywie ruchu ludowego: Front, jego zdaniem, powinien być organizacją chłopów, niezależną od PCR, a jego zadaniem powinna być ochrona własności prywatnej i poprawa sytuacji ekonomicznej, społecznej i politycznej ludności wiejskiej. Zăroni, Belea, Ghelmegeanu oraz inni liderzy liczyli na bezpośrednią pomoc ze strony premiera Grozy, który był równocześnie prezesem Frontu. Entuzjazm tej grupy „autonomistów”, lub „kułaków”, jak nazwali ich komuniści, zgasł po wyborach parlamentarnych w listopadzie $1946 \mathrm{r}$. Zaczęli wtedy rozumieć, że Groza jest jedynie marionetką i nie tylko nie chce angażować się bezpośrednio w organizację Frontu, ale także nie ma zamiaru powstrzymania coraz to bardziej zuchwałych ingerencji komunistów w kierowanie ugrupowaniem?.

Opór tej grupy ustał wraz z rozpoczęciem akcji „reorganizacji” FO, to jest weryfikacji i wykluczania z organizacji elementów „wrogich” i „niezgodnych z linią" partii komunistycznej. Różnice zdań między tymi dwiema wizjami wywoływały niezadowolenie i tarcia po obu stronach, zarówno na poziomie kierownictwa centralnego, jak i w strukturach terytorialnych. Proces ten zakończył się w 1953 r., wraz z ,samorozwiązaniem” FO - de facto przyłączeniem tego ugrupowania do Rumuńskiej Partii Robotniczej ${ }^{10}$.

Okręgowy Timiș Narodowych Archiwów Rumunii], fond Comitetul Județean Timiș-Torontal. Organizația Frontului Plugarilor, dos. 3/1945, f. 220.

9 S. Radu, „Tovarăși de drum”: Frontul Plugarilor și Partidul Comunist în anii 1944-1947, „Revista istorică”, t. 23, 2012, nr 1-2, s. 107-138.

${ }^{10}$ Rumuńska Partia Robotnicza (Partidul Muncitoresc Român, PMR) to nazwa przyjęta przez Rumuńską Partię Komunistyczną po przyłączeniu Partii Socjaldemokratycznej w lutym 1948 r. (N. Jurca, Istoria social-democrației din România, București 1994, s. 364-383). 


\section{Struktura organizacyjna Frontu Oraczy}

Pierwszy po II wojnie światowej, a drugi w historii ugrupowania Narodowy Kongres Frontu Oraczy odbył się w dniach 24-27 czerwca 1945 r. $\mathrm{Z}$ tej okazji przyjęto nowy statut, na stanowisku prezesa zatwierdzono Grozę, wybrano nowy Komitet Centralny (złożony z 158 członków) oraz Komitet Wykonawczy (złożony z 21 członków), który zarządzał organizacją $^{11}$. Statut stwierdzał, że FO jest walczącym stronnictwem wiejskiej klasy pracującej, zrodzonym z walki ubogich chłopów o ziemię, z walki przeciwko wyzyskującym obszarnikom, bankierom i ich rządom. W statucie podkreślono także sojusz z klasą pracującą miast. Charakter i cele organizacji zostały jasno zdefiniowane: 1 . FO jest stronnictwem pracujących chłopów, to jest chłopów, którzy samodzielnie uprawiają ziemię, bez wyzyskiwania cudzej pracy; 2. Celem FO jest organizowanie i mobilizowanie wszystkich chłopów do walki o poprawę ich statusu materialnego i kulturalnego. By osiągnąć ten cel, FO miał: ,a. Wzmóc walkę przeciwko reakcji na terenie wsi aż do jej całkowitej likwidacji. b. Wzmocnić i pogłębić współpracę z klasą pracującą miast oraz reprezentującą ją Rumuńską Partią Komunistyczną, w celu utrzymania, utwierdzenia i poszerzania demokracji”. Linia polityczna (i obowiązki z niej wypływające) miała być prowadzona „za pośrednictwem codziennej pracy organizatorskiej wśród rolników, na wsi"12.

W skład struktur organizacyjnych FO wchodziły: Kongres Generalny (który zatwierdzał statut, program oraz organa kierownicze organizacji); Komitet Centralny (wyższy organ kierowniczy, który posiadał inicjatywę i podejmował decyzje kluczowe dla organizacji); komitety powiatowe i okręgowe. Podstawową komórką organizacyjną była organizacja sołecka. W ramach organizacji okręgowej podział pracy wyglądał następująco: Biuro Okręgowe składało się z prezesa organizacji okręgowej, wiceprezesów oraz sekretarzy: odpowiedzialnego za resort organizacyjny, odpowiedzialnego za resort edukacji, prasy i propagandy, odpowiedzialnej za

${ }^{11}$ Primul Congres general al Frontului Plugarilor, București 1945, s. 342-347; Comitetul Central al Frontului Plugarilor ales de Congres, „Scânteia”, 1 VII 1945.

12 „a. Să intensifice lupta împotriva reacțiunei de la sate până la completa și definitiva ei lichidare. b. Să întărescă și să adâncească colaborarea cu clasa muncitoare de la orașe și cu partidul său Partidul Comunist Român, pentru păstrarea, consolidarea și dezvoltarea democrației”; , prin muncă organizatorică de zi cu zi până la plugarii din sate", Statut de organizare aprobat de Congresul general al Frontului Plugarilor în ședința din 27 iunie 1945, Arhivele Naționale Istorice Centrale București, ANIC [Centralne Historyczne Archiwa Narodowe w Bukareszcie], Arhiva CC al PCR, fond Frontul Plugarilor, rola 430, cadrele 200-202; Statut de Organizare al Frontului Plugarilor, w: Ce trebuie să știe un luptător al Frontului Plugarilor, [București 1945], s. 8-13. 
organizowanie kobiet, odpowiedzialnego za komisję okręgową młodzieży chłopskiej, odpowiedzialnego za resort administracyjno-finansowy, odpowiedzialnego za resort gospodarczy. Najważniejszy był resort organizacyjny. W zakres jego obowiązków ogólnych wchodziło przekazywanie rolnikom w gminach linii politycznej i zadań wyznaczonych przez Komitet Okręgowy; ciągłe raportowanie na temat sytuacji politycznej i stanu organizacyjnego stronnictwa w okregu; ewidencjonowanie kadr kierowniczych, począwszy od instruktorów okręgowych, członków komitetu okręgowego, komitetów powiatowych i gminnych; nadzorowanie i wspomaganie rozwoju ideologicznego kadr, ich morale i sposobu wypełniania przez nich obowiązków partyjnych; nadzorowanie, wspomaganie i rozliczanie wykonania planów roboczych komitetu okręgowego. Drugim co do ważności resortem był resort edukacji, prasy i propagandy. Ogólnymi obowiązkami tegoż były: stałe podnoszenie poziomu politycznego i kulturalnego członków komitetu okręgowego i wszystkich członków FO; oddawanie do dyspozycji biura i komitetu okręgowego potrzebnych materiałów propagandowych, w celu tworzenia wśród pracującej klasy rolniczej w okręgu świadomości ścisłego sojuszu z klasą robotniczą; upowszechnianie braterstwa między rolnikami rumuńskimi a rolnikami innych narodowości zamieszkujących Rumunię; wzmacnianie przyjaźni z narodami sąsiednich państw demokratycznych, a zwłaszcza z narodami Związku Radzieckiego i „wszystkimi narodami, które walczą o pokój i wolność"; wskazywanie pracującej klasie rolniczej, że „jej śmiertelnym wrogiem jest reakcja, imperialistyczne trusty wywołujące wojny, reakcyjni obszarnicy, wywłaszczeni ze swych dóbr i ich pomagierzy we wsiach, kułacy". Resort finansowo-administracyjny miał ogólnie za zadanie: zapewnianie strukturom organizacyjnym w okręgu środków materialnych, finansowych, żywności, odzieży, domów wypoczynkowych dla chorych aktywistów, itp., potrzebnych do wykonywania zadań politycznych i organizacyjnych; ewidencjonowanie partyjnych dób materialnych w danym okręgu i zarządzanie nimi. W końcu, zadaniami komisji okręgowej ds. młodzieży chłopskiej było organizowanie, edukowanie i mobilizowanie młodzieży rolniczej we wsiach, ponieważ „młodzi oracze we wsiach są ogromną rezerwą sił bojowych oraz przyszłością naszego stronnictwa i ojczyzny" ${ }^{3}$.

13 „dușmanul ei de moarte este reacțiunea, trusturile imperialiste provocatoare de război, moșierii reacționari expropriați de moșiile lor, uneltele acestora din sat, chiaburii”; ,tinerii plugari muncitori de la sate sunt o imensă rezervă de forțe luptătoare și viitorul partidului nostru și al patriei”, Instrucțiuni transmise de Comitetul Executiv al Frontului Plugarilor pentru organizarea Comitetelor Județene, nedatat, Serviciul Județean Hunedoara al Arhivelor Naționale ale României, SJHANR [Oddział 


\section{Organizacja propagandy}

W latach 1949-1953 Front Oraczy miał komórki organizacyjne niemal we wszystkich sołectwach i gminach wiejskich Rumunii, ich podstawowym zadaniem zaś było transmitowanie propagandy PCR wśród chłopów, tłumaczenie na język zrozumiały dla mieszkańców wsi narzuconych przez komunistów tez partyjnych, zwłaszcza tych związanych z socjalistycznymi przekształceniami gospodarki rolnej, wagi partii w życiu chłopa, modernizacji wsi itp. W tym celu Front musiał wykształcić i przygotować nowe kadry „instruktorów” i „aktywistów partyjnych”, którzy zaniosą przesłanie komunistów do chłopskich domów, jak również zorganizować akcję propagandową, wypracować dyskurs zrozumiały dla chłopów - w dużej części analfabetów, głęboko religijnych i niezwykle nieufnych wobec komunistycznych haseł, takich jak „dyktatura proletariatu”, „demokracja ludowa” albo „kolektywizacja rolnictwa”.

Propaganda w środowiskach wiejskich została zatem przygotowana zgodnie z modelem radzieckim i uznana za najważniejsze narzędzie do formowania świadomości politycznej każdego obywatela, zdecydowanego walczyć o swoje ideały polityczne. Wychodząc z założenia ideologicznego, totalitarnego w swojej istocie, zgodnie z którym ,propaganda jest zasadniczą kwestią w kształtowaniu nowego człowieka"14, liderzy FO oparli propagandę na pięciu głównych filarach: propagandy politycznej, kulturalnej, informacyjnej i prasowej, kołach zawodowych oraz kształceniu kadr ${ }^{15}$.

Sekcja propagandy politycznej miała za zadanie opracowywanie materiałów propagandowych (hasła, plakaty, itp.), jak również prowadzenie ewidencji aktywności terenowej instruktorów odpowiedzialnych za propagandę. Sekcja ta miała z uwagą śledzić aktywność także innych sekcji, nie tylko zapewniając im materiały, ale także wskazując ścieżkę, jaką miały podążać. Sekcja propagandy kulturalnej organizowała „wydarzenia kulturalne”, w celu głoszenia „linii politycznej Frontu Oraczy”. Do obowiązków tej sekcji należało: zakładanie i koordynowanie działalności chórów, trup teatralnych, ekip sportowych, organizowanie akade-

Okręgowy Hunedoara Narodowych Archiwów Rumunii], fond Frontul Plugarilor. Comitetul Județean Hunedoara, dos. 1/1944, f. 1-5.

14 „propaganda este problema esențială a formării omului nou”, P. Kenez, The Birth of the Propaganda State: Soviet Methods of Mass Mobilization, 1917-1929, Cambridge 1985, s. 252. Szerzej na temat komunistycznej propagandy zob. V. Reisky de Dubnic, Communist Propaganda Methods. A Case Study on Czechoslovakia, New York 1960, s. 252; L. Fraser, Propaganda, London-New York-Toronto 1957, rozdz. „Communism and Propaganda", s.123-140.

${ }^{15}$ Organizarea Propagandei, w: Ce trebuie să știe un luptător al Frontului Plugarilor, s. 14-30. 
mii, wieczorków kulturalnych, organizowanie kół czytelniczych, itd. Sekcja informacji i prasy była odpowiedzialna za wydawanie wszystkich periodyków partii, zwłaszcza gazety „Frontul Plugarilor”. Poza tym koordynowała i monitorowała dystrybucję wydawnictw FO w terenie (także broszur propagandowych, plakatów, dokumentów urzędowych itp.). Teksty dziennikarskie w gazecie były redagowane językiem zrozumiałym dla rolników, wolą kierownictwa partii zaś było, by łamy czasopisma były miejscem na dyskusję dla wszystkich, którzy pragnęli poprawy statusu chłopstwa. Sekcja kół zawodowych miała za zadanie włączenie do FO intelektualistów, co było nader ważne w kontekście początkowej nieufności lub wręcz wrogości członków tej partii wobec ludzi wykształconych. Piątym filarem propagandy FO była Szkoła kadr ${ }^{16}$, której poświęcano wyjątkową uwagę ze względu na jej cel - przygotowywanie, zgodnie z modelem komunistycznym, aktywistów i działaczy partyjnych (jednym słowem: kadry), ludzi wiernych nowemu ustrojowi komunistycznemu, świadomych, dobrze zindoktrynowanych, którzy mieli propagować linię FO, a w rezultacie linię PCR w środowiskach wiejskich.

\section{Uczestnictwo Frontu Oraczy w wyborach parlamentarnych 19 listopada 1946 r.}

Najważniejsze wydarzenie polityczne w Rumunii, po powołaniu proradzieckiego rządu Grozy, stanowiły listopadowe wybory parlamentarne, wygrane przez komunistów za pomocą fałszerstw wyborczych ${ }^{17}$. W warunkach, w których popularność komunistów była wciąż bardzo słaba, poświęcili oni szczególną uwagę dysydentom z partii przedwojennych oraz „poputczykom”. Działania przedwyborcze FO zostały ustalone przez komunistów w trakcie Posiedzenia Plenarnego KC PCR z 25-28 stycznia 1946 r., kiedy to także postanowiono wystawić jedną listę dla wszystkich rządzących sił politycznych. Uczestnictwo Oraczy u boku komunistów w wyborach z listopada 1946 r. zostało zatwierdzone przez KC FO 18 marca tego samego roku ${ }^{18}$. Istniał też projekt samodzielnego startu FO w wyborach, w celu pogłębienia konfuzji w środowiskach wiejskich co do oficjalnego rozdziału między PCR a FO.W tym to sensie jeden z przywódców FO odnotował: „jedynie w taki sposób możemy zapozorować pewną

${ }^{16}$ Dla tego zagadnienia zob.: S. Radu, Party Education in Communist Romania. Case Study: the Establishment and Organization of the Ploughmen's Front's Schools of Cadres (1948), „Slovanský přehled” 2012, nr 1-2, s. 65-79.

${ }^{17}$ V. Țârău, Alegeri fără opțiune. Primele scrutinuri parlamentare din Centrul și Estul Europei după cel de-al Doilea Război Mondial, Cluj-Napoca 2005.

18 „Frontul Plugarilor”, 21 II 1946. 
niezależność, zwłaszcza jeśli Front Oraczy przystąpi do wyborów jako samodzielna organizacja"19.

Zgodnie z programem ustalonym przez komunistów w styczniu, w maju została określona platforma programowa sojuszu. 17 maja platforma ta została ratyfikowana przez partię komunistyczną, partię socjaldemokratyczną, FO, Narodową Partię Ludową, dysydentów liberalnych pod przywództwem Gheorghe Tătărescu oraz dysydentów z Partii Narodowo-Chłopskiej pod wodzą Antona Alexandrescu. W ten sposób powstał Blok Partii Demokratycznych (Blocul Partidelor Democratice, BPD) ${ }^{20}$. Na podstawie protokołu przyjętego przez BPD, FO otrzymał 12\% miejsc na listach wyborczych, dzięki czemu mógł wystawić 85 kandydatów ${ }^{21}$.

W okresie kampanii wyborczych przywódcy Frontu, za pośrednictwem organizacji gminnych i sołeckich, zajmowali się ciągłym badaniem nastrojów w środowiskach wiejskich, wymagając od kadr lokalnych regularnego nasyłania sprawozdań na temat nastrojów chłopstwa. W okólnikach wysyłanych komórkom partyjnym w gminach wielokrotnie nakazywano członkom Frontu aktywność lub wręcz wymagano od nich, by znajdywali możliwości natychmiastowej pomocy w trudnościach, z którymi rolnicy nie mogli się uporać. Odpowiedzi zwrotne komórek sołeckich i gminnych były częstokroć pesymistyczne, ponieważ i one stały w obliczu poważnych problemów w sferze logistyki i infrastruktury, które nie pozwalały na natychmiastową interwencję, zarówno w wypadku akcji propagandowych, jak i niesienia pomocy wśród chłopów.

Bardzo interesujące szczegóły odnośnie do przygotowywania kampanii wyborczej przez aktywistów FO zawierają doniesienia sporządzane przez organizacje powiatowe. $Z$ prowincji spływały do kierownictwa centralnego petycje o rozwiązanie różnorakich problemów o wyraźnym charakterze przedwyborczym: postulowano, by zapewnić dobre zaopatrzenie chłopów w żywność oraz inne produkty, których brakowało w wiejskich sklepach oraz spółdzielniach (w warunkach suszy panującej w większej części kraju); by usunąć ze struktur administracyjnych urzędników, którzy nie są członkami żadnej z partii tworzących BPD lub takich, którzy wyrażają niechęć wobec BPD; by wyznaczyć tych lub innych członków Frontu do pracy przy

19 „numai așa putem da o aparență de oarecare independență, mai ales dacă Frontul Plugarilor va merge în alegeri ca organizație separată”, Ședința cu membrii de partid ai Frontultui Plugarilor, 13 noiembrie 1945, cadrele 2-13, ANIC, fond CC al PCR - Cancelarie, dos. 101/1945, f. 4.

${ }^{20}$ D. Giurescu, Falsificatorii. Alegerile din 1946, București 2006, s. 194-196; G. Onișoru, Alianțe și confruntări între partidele politice din România, București 1996, s. 230; I. Zainea i in., Democrație Occidentală și Democrație populară. Evoluția spectrului politic în Nord Vestul României 1944-1950, Oradea 2004, s. 149-165, 170.

${ }^{21}$ Constituirea Blocului Partidelor Democratice, „Frontul Plugarilor”, 29 IX 1946. 
przedsięwzięciach politycznych i wyborczych ${ }^{22}$; by zweryfikować działalność niektórych organizacji sołeckich i wykluczyć członków podejrzewanych o sprzyjanie Partii Narodowo-Chłopskiej ${ }^{23}$; by zezwolić na rekwizycję należących do osób prywatnych samochodów i ciężarówek, tak, by można je było wykorzystać w kampanii wyborczej ${ }^{24}$. Niekiedy zgłaszano dość zabawne zapotrzebowania, jak na przykład prośby o skierowanie zespołów muzycznych lub opłacenie ich występów ${ }^{25}$.

Kampania wyborcza BPD przybrała na intensywności pod koniec września 1946 r., kiedy to kierownictwo centralne ustaliło „plany pracy”. Mityngi wyborcze zostały przygotowane zawczasu i ich plany przekazane działaczom z organizacji okręgowych. Instrukcje kierownictwa centralnego co do dnia 19 listopada 1946 r. były bardzo jasne:

1. Należy zawczasu przygotować programy kulturalno-artystyczne w sołectwach, zabawy wiejskie, akademie, wieczorki w lokalach i świetlicach, tak, by uczynić z dnia wyborów święto; 2. Należy przygotować przemarsze młodzieży wiejskiej przez wsie z muzykantami, proporcami i transparentami w momencie rozpoczęcia głosowania; 3. Organizacje młodzieży wiejskiej zawczasu zamówią muzykantów na dzień wyborów ${ }^{26}$.

W miarę zbliżania się terminu wyborów kampania stawała się coraz agresywniejsza. Nie pozostawiano miejsca na przypadek. „Siły demokratyczne” musiały wygrać z „reakcyjnymi” (czyli Partią Narodowo-Chłopską i Partią Narodowo-Liberalną). Jeszcze we wrześniu, pod bezpośrednim nadzorem przedstawicieli PCR, sporządzono wykazy kandydatów FO na listach wyborczych, mężów zaufania w lokalach wyborczych, członków komisji wyborczych oraz listy merów i wicemerów - członków tej formacji. Osoby te poddano starannej weryfikacji, by nie dopuścić do zachowań niezgodnych z „naszą demokratyczną linią"27.

${ }^{22}$ SJHANR, fond Frontul Plugarilor. Comitetul de Plasă Petroșani, dos. 7/1946, f. $18,40-44$.

${ }^{23}$ Iuliu Maniu był przewodniczącym Partii Narodowo-Chłopskiej.

${ }^{24}$ SJHANR, fond Frontul Plugarilor. Comitetul de Plasă Petroșani, dos. 7/1946, f. $30,34,35,80,81,87$.

${ }^{25}$ Ibidem, f. 65.

${ }^{26}, 1$. Organizarea din vreme a problemelor culturale artistice pe sate, jocuri de țară, serbări, festivaluri seara în localuri și în șezători pentru a putea transforma ziua propriu-zisă a alegerilor în zi de sărbătoare; 2. Organizarea coloanelor tineretului plugăresc pe sate în frunte cu muzici, steaguri și placarde care vor merge în fruntea sătenilor spre secțiunile de votare în momentul când începe votarea; 3. Organizațiile tineretului plugăresc vor angaja din vreme lăutari la sate pentru ziua alegerilor”, „Plan de muncă" al organizației Frontul Plugarilor Petroșani pentru campania electorală, 28 septembrie 1946, ibidem, f. 121.

${ }^{27}$ I. Zainea i in., op. cit., s. 149-165, 168. 
W ciągu października i listopada 1946 r. propagandziści FO przemierzyli powiat po powiecie z propagandą przedwyborczą. Pomimo ich wysiłków i optymistycznych deklaracji, z raportów złożonych przez nich oraz przez sekretarzy politycznych na poziomie okręgów wynikało, że w środowiskach wiejskich większe wpływy ma Partia Narodowo-Chłopska. Co więcej, na stronę partii Iuliu Maniu przeszły niektóre z komitetów powiatowych $\mathrm{FO}^{28}$. Bezpośrednio przez wyborami listopadowymi organizacje terytorialne FO sygnalizowały kierownictwu centralnemu silną nerwowość wśród ludności, która w napięciu oczekuje dnia wyborów. Nerwowość była spowodowana - według członków Frontu - „przez pogłoski rozsiewane przez ludzi Maniu i Brătianu, oczerniające Blok", zgodnie z którymi ten miał wprowadzić system kołchozowy „i że wkrótce wybuchnie wojna między Amerykanami i Rosjanami" ${ }^{29}$.

Ostatecznie - jak wiadomo ${ }^{30}$ - wybory zostały przez komunistów sfałszowane. Przedwojenne partie stanowczo oprotestowały wynik wyborów, kierując memoranda do rządu, króla i aliantów. Król Michał I postanowił mimo to otworzyć pierwsze posiedzenie Izby Deputowanych, odczytując mowę tronową w dniu 1 grudnia 1946 r., co oznaczało potwierdzenie legalności wyborów. Spomiędzy 347 miejsc w parlamencie zdobytych przez BPD w wyborach, FO przyznano 71.

\section{Reorganizacja Frontu Oraczy}

W trakcie posiedzeń zwołanych przez kierownictwo FO w celu analizy wyników wyborów, zidentyfikowano szeroką gamę przyczyn słabych wyników, jakie osiągnęła organizacja: wiele spośród „osób odpowiedzialnych" nie spełniło oczekiwań, a część z nich przyłączyła się do sił „reakcyjnych”; liczne kadry zaangażowane w kampanię wyborczą nie były wystarczająco przygotowane politycznie, by przyciągnąć elektorat, nie miały one także wystarczającej wiarygodności w środowiskach wiejskich; partia rozwinęła się na terytorium całego kraju w tempie zbyt szybkim, wiele zaś organizacji terytorialnych nie posiadało potrzebnych struktur; większość lokalnych elit, czyli nauczyciele i duchowni, niektórzy merowie, notariusze i żandarmi, niektórzy z nich formalnie należący do FO, poparła Partię Narodowo-Chłopską. Antyrządowy kli-

${ }^{28}$ Ibidem, s. 170.

${ }^{29}$ „de svonurile lansate de maniști și brătieniști împotriva Blocului”; „și că în curând va fi război între anglo-americani și ruși”, Raport despre activitatea Frontului Plugarilor din plasa Petroșani pe luna septembrie 1946, nedatat, SJHANR, fond Frontul Plugarilor. Comitetul de Plasă Petroșani, dos. 7/1946, f. 111-112.

30 V. Țârău, op. cit., s. 427-493. 
mat był równocześnie podgrzewany przez wracających z niewoli radzieckiej rumuńskich żołnierzy, którzy naocznie przekonali się, jak wygląda rzeczywistość komunistyczna w Związku Radzieckim, i którzy trafnie oceniali kierunek, w jakim zmierzała polityka rządu Grozy; pogłoski rozsiewane przez „reakcję” na temat utworzenia kołchozów, gdyby BPD wygrał wybory. Niektórzy sekretarze okręgowi PCR wskazywali na „pasywizm Frontu Oraczy" ${ }^{31}$. Poufne dokumenty na temat sytuacji Frontu na prowincji w okresie wyborów mówią wręcz o aktach zdrady, których mieli się dopuścić lokalni liderzy, o paktowaniu z wrogami klasowymi. W ten sposób, za pomocą mało wiarygodnych argumentów, działacze próbowali wytłumaczyć brak zainteresowania chłopów „demokratycznymi" programami politycznymi Frontu i jego sojuszników z BPD ${ }^{32}$. Warto przytoczyć fragment sprawozdania Komitetu Okręgowego Severin Frontu Oraczy, który naświetla w jasny sposób zachowanie członków tej organizacji podczas wyborów z listopada 1946 r.:

Dzień 19 listopada 1946 stanowił całościowy sprawdzian naszych sił w okręgu. Sprawdzian ten był brutalnym rozczarowaniem, ponieważ w obliczu liczby członków organizacji okręgowej liczyliśmy na lepsze wyniki. Z całkowitej liczby 7000 zapisanych członków ponad połowa dokonała dezercji, głosując na reakcyjnych kandydatów. W obliczu sytuacji politycznej spowodowanej przez takie zachowanie biuro polityczne komitetu okręgowego wraz z prezesami komitetów powiatowych postanowili rozpocząć całościową reorganizację komitetów gminnych i powiatowych, by w przyszłości organizację tworzył i formował element zdolny i uczciwy, by uniknąć podobnych niespodzianek, jak ta z 19 listopada $1946^{33}$.

${ }^{31}$ Ș. Rădulescu-Zoner, Politica PCR și a tovarășilor de drum, București 1997, Analele Sighet, nr 5, s. 198; D. Șandru, Comunizarea societății românești în anii 1944-1947, București 2007, s. 217, 218.

32 ANIC, Arhiva CC al PCR, fond Frontul Plugarilor, rola 430, cadrele 824, 825.

33 „Ziua de 19 Noembrie 1946 a însemnat o completă verficare a forțelor noastre din județ. Această verificare a fost o cruntă deziluzie, deoarece față de numărul membrilor din organizația județeană a Frontului Plugarilor am sperat într-o mai bună comportare a acestora. Din totalul de 7.000 membri înscriși, mai bine de jumătate a dezertat și au votat cu reacțiunea. Astfel fiind situația politică creată prin această comportare, biroul politic al comitetului județean și cu președinții de plasă au luat hotărârea de a porni la o complectă organizare a comitetelor comunale și de plasă pentru ca pe viitor această organizație să fie formată și ridicată prin elemente capabile și sincere pentru ca să nu mai fie rezervate astfel de surprize cum a fost cea de la 19 Noiembrie 1946", Raportul Comitetului Județean Severin al Frontului Plugarilor din noiembrie 1946, decembrie 1946, SJTANR, fond Comitetul Județean Severin. Organizația Frontului Plugarilor, dos. 2/1946, f. 7. 
Rozczarowujące wyniki osiągnięte przez koalicję BPD, które skłoniły komunistów do sfałszowania wyników, nie pozostały bez konsekwencji. Na początku 1947 r. odbyło się w Bukareszcie wspólne posiedzenie kierownictwa partii komunistycznej i FO, podczas którego poddano analizie istniejącą sytuację oraz środki, jakie powinny zostać powzięte w celu zwiększenia skuteczności propagandy w środowiskach wiejskich. Przy tej okazji FO otrzymał zadanie zwiększenia swojej aktywności we wsiach, w których środki propagandowe nie przyniosły rezultatów. W tym celu partia miała dokonać „oczyszczenia” w szeregach swoich członków. Była tu mowa o tych, którzy nie wykazali odpowiedniego poziomu ideologicznego. W praktyce zadanie to polegało na reorganizacji struktur terytorialnych na wszystkich poziomach.

„Reorganizacja”, rozpoczęta w 1947 r., stanowiła pierwszy etap procesu, który miał się zakończyć samorozwiązaniem FO w roku 1953. W jej ramach, w celu „naprostowania sytuacji”, narzucono „natychmiastową weryfikację i reorganizację wszystkich komitetów sołeckich, gminnych i powiatowych, za pomocą wprowadzenia elementu uczciwego i szczerego, który dnia 19 listopada zdał pozytywnie egzamin i dowiódł w dostateczny sposób, że ma demokratyczne przekonania, oraz z jednoczesnym usunięciem wszystkich tych, którzy wykazali bierność, nieszczerość i brak odwagi". Reorganizacja komitetów sołeckich, gminnych, powiatowych i okręgowych miała być przeprowadzona z „czujnością”, tak by „nie pozwolić na wniknięcie w szeregi naszej organizacji agentów partii przedwojennych, które wciąż próbują przełamać nasze organizacje i równocześnie rozerwać naszą ścisłą współpracę z innymi partiami politycznymi" ${ }^{34}$.

Rozpoczęcie „reorganizacji” FO oznaczało prawdziwą ofensywę partii komunistycznej w celu całkowitego i bezpośredniego przejęcia kontroli nad „światem wiejskim”. Znaczna liczba dokumentów archiwalnych poświadcza zastępowanie merów gmin - członków FO, działaczami PCR. Ofensywa komunistów spotkała się z aprobatą przywódców FO, którzy także ją wyjaśniali i tłumaczyli, chcąc przypochlebić się niektórym członkom

34 „verificarea imediată și reorganizarea tuturor comitetelor sătești comunale și de plasă cu introducerea elementelor cinstite și sincere de la 19 Noiembrie care au trecut examenul cu succes și au făcut dovezi suficiente despre convingerile lor democratice, precum și înlăturarea tuturor acelora care s-au arătat pasivi, nesinceri și lipsiți de curaj”; ,a nu lăsa să pătrundă în rândurile organizațiilor noastre agenți ai paridelor istorice, care tot timpul urmăresc să spargă organizațiunile noastre, în acelaș timp și colaborarea în bloc cu celelalte partide politice", Planul de muncă al Organizației Județene Hunedoara a Partidului Frontul Plugarilor adoptat în ședința din 8 ianuarie 1947, 29 ianuarie 1947, SJTANR, fond Comitetul Regional PCR Hunedoara, dos. 6/1947, f. 57, 59. 
PCR. W rzeczywistości sprawy uległy pogorszeniu po usunięciu z rządu grupy Tătărescu ${ }^{35}$. Na przykład, podczas posiedzenia Komitetu Okręgowego Severin członkowie komitetu donosili o wielu poważnych naruszeniach zasad współpracy, których szczytem było rozpowszechnianie przez komunistów wieści, jakoby wnet z rządu miał być usunięty także FO, tak jak wyrzucono Tătărescu ${ }^{36}$.

W latach 1948-1953 przez szeregi FO przeszło kilka fal czystek - usuwano tych członków, którzy nie spełniali wymagań na danym etapie ewolucji partii komunistycznej, przekształcającej się wówczas w partię robotniczą. W tym procesie ciągłego „oczyszczania” FO istotną rolę odgrywały organizacje sołeckie PMR ${ }^{37}$. W tym okresie, jak wynika z dokumentów archiwalnych, wykluczano z partii głównie nauczycieli i duchownych.

\section{Zaangażowanie Frontu Oraczy w przeprowadzenie reformy rolnej oraz w proces \\ kolektywizacji rolnictwa}

Likwidacja prywatnej własności gruntów rolnych oraz ustanowienie kolektywnego modelu gospodarki rolnej było jedną z wielu idei przejętych $\mathrm{z}$ modelu radzieckiego. Idee te miały o wiele starsze korzenie i można je odnaleźć w wielu projektach utopii w ostatnich dwóch tysiącleciach, jednak sposób, w jaki zostały one zaszczepione w Rumunii, ma ścisły związek z radzieckim modelem socjalistycznych przekształceń gospodarki rolnej. ZSRR, zajmując kraje Europy Środkowo-Wschodniej, miał przygotowaną zawczasu strategię sowietyzacji, którą stosował we wszystkich krajach swojej strefy dominacji, kolektywizacja rolnictwa zajmowała zaś istotne miejsce w ramach tej strategii ${ }^{38}$.

${ }^{35}$ Inny „towarzysz drogi” PCR, odsunięty przez komunistów od władzy w listopadzie $1947 \mathrm{r}$.

${ }^{36}$ Raport al organizației județene Severin a Frontului Plugarilor către Comitetul Central al Frontului Plugarilor, 21 noiembrie 1947, SJTANR, fond Comitetul Județean Severin Organizația Frontului Plugarilor, dos. 4/1947, f. 38, 39.

${ }^{37}$ SJTANR, fond Comitetul Județean Severin Organizația Frontului Plugarilor, dos. 5/1948, f. 241.

${ }^{38}$ Transforming Peasants, Property and Power: The Collectivization of Agriculture in Romania, 1949-1962, red. C. Iordachi, D. Dobrincu, Budapest 2009; G. Kligman, K. Verdery, Peasants under Siege: The Collectivization of Romanian Agriculture, 1949-1962, Princeton 2011. Na temat kolektywizacji rolnictwa w ZSRR i Europie Wschodniej zob.: R. Conquest, The Harvest of Sorrow: Soviet Collectivization and the Terror-Famine, New York 1986; R.W. Davies, The Socialist Offensive: The Collectivisation of Soviet Agriculture, 1929-1930, London 1980; S. Fitzpatrick, Stalin's Peasants: Resistance and Survival in the Russian Village after Collectivization, New York 1994; Soviet and East European Agriculture, red. J. F. Karcz, Berkeley-Los Angeles 1967; M. Lewin, Russian Peasants and Soviet Power: A Study of 
Proces kolektywizacji rolnictwa został poprzedzony szeroko zakrojoną reformą rolną, poprzez którą nowe władze próbowały zdobyć kapitał polityczny wśród chłopów, stanowiących około 80\% ludności Rumunii. Należy w tym miejscu zaznaczyć, że reforma ta miała przede wszystkim cel polityczny, cele zaś gospodarcze i społeczne były drugorzędne. Reforma rolna, przygotowana i przeprowadzona przez rząd Grozy, który w ten sposób wzmocnił swoją pozycję, uderzać miała głównie w członków mniejszości niemieckiej w Rumunii (oskarżanych o kolaborację z nazistami), dopiero w dalszej kolejności zaś była działaniem wymierzonym przeciwko obszarnikom, tak jak to przedstawiano w dyskursie propagandowym komunistów i FO ${ }^{39}$.

Rząd Grozy doprowadził do uchwalenia ustawy o reformie rolnej już po dwóch tygodniach od przejęcia władzy. Reforma, według oficjalnej propagandy, miała być daleko bardziej demokratyczna i radykalna niż ta przeprowadzona przez „,burżuazyjne” rządy w latach 1919-1921. De facto jeszcze w marcu 1945 r. w wielu regionach kraju chłopi, za zachętą komunistów i FO, przystąpili do podziału gruntów. Także i działacze FO na poziomie organizacji okręgowych byli bezpośrednio zaangażowani w przeprowadzenie reformy rolnej, w wielu wypadkach sprawując funkcje przewodniczących komisji uwłaszczeniowych.

Zaangażowanie to, jak również szczere deklaracje liderów Frontu popierające własność prywatną w roku 1945, zbudowały im niezwykły kapitał polityczny. W następujących miesiącach i latach ich partia odnotowała gwałtowny napływ nowych członków. Należy tu zwrócić uwagę na fakt, że chłopi rumuńscy jeszcze w okresie przedwojennym kojarzyli partię komunistyczną z wywłaszczeniami i kolektywizacją, FO zaś wydawał im się o wiele atrakcyjniejszą alternatywą, bardziej zbliżoną do chłopskiego obrazu świata, gdzie ideologiczne uniwersum było oparte na własności ziemi i prawosławiu. Front wydawał się bronić tych wartości, chłopi zaś nie musieli rozumieć podporządkowania tej formacji liderom partii komunistycznej.

Nastawienie komunistów wobec kolektywizacji rolnictwa - początkowo umiarkowane - zmieniło się radykalnie po przejęciu przez nich

Collectivization, New York 1968; The War Against the Peasantry, 1927-1930: The Tragedy of the Soviet Countryside, red. L. Viola i in., New Haven-London 2005; Collectivization of Agriculture in Eastern Europe, red. I. T. Sanders, Lexington 1958; J. Sokolovsky, Peasants and Power: State Autonomy and the Collectivization of Agriculture in Eastern Europe, Boulder, Colo. 1990; Transforming Rural Societies. Agrarian Property and Agrarianism in East Central Europe in the Nineteenth and Twentieth Centuries, red. D. Müller, A. Harre, InnsbrückWien-Bozen 2010.

${ }^{39}$ Szerzej zob.: D. Șandru, Reforma agrară din 1945 și țărănimea germană din România, București 2009. 
całkowitej kontroli nad krajem. Po wyeliminowaniu partii przedwojennych, zmuszeniu króla Michała I do abdykacji, przejęciu systemu finansowego i przemysłu przez nacjonalizację nie musieli już ukrywać swoich intencji wobec wsi. W dniach 3-5 marca 1949 r. na Plenum KC Rumuńskiej Partii Robotniczej (Partidul Muncitoresc Român, PMR) podjęto decyzję o rozpoczęciu procesu kolektywizacji rolnictwa w Rumunii. Najistotniejsze elementy tego procesu, dla którego wzorem był model radziecki, polegały na wykorzystaniu mechanizmów prawodawczych i instytucji państwowych, na terrorze i przemocy, wreszcie terminologii i języku. Jeśli odniesiemy się jedynie do frazeologii, zwrócimy uwagę, że była ona identyczna z tą stosowaną w latach dwudziestych i trzydziestych w ZSRR: „,polityka odgradzania kułaków”, „rozkułaczanie” i likwidacja kułaków jako klasy itp. Także instytucje i struktury rolnictwa kolektywnego zostały przejęte wprost z modelu radzieckiego, po przetłumaczeniu z języka rosyjskiego ich nazw, modeli organizacyjnych i regulaminów. W ten sposób Kolektywne Gospodarstwa Rolne (Gospodăriile Agricole Colective, GAC) stały się rumuńskim odpowiednikiem kołchozów, Państwowe Gospodarstwa Rolne (Gospodăriile Agricole de Stat) były ekwiwalentem sowchozów, Stowarzyszenia Rolne (Întovărășirile Agricole) - rumuńskimi TOZ-ami (Towarzystwo Wspólnej Uprawy Ziemi), stacje maszyn i traktorów zaś odpowiednikiem sowieckich SMT (Stațiunea de Mașini și Tractoare - Stacja Maszynowo-Traktorowa) ${ }^{40}$.

Po przyjęciu przez komunistów rezolucji na temat socjalistycznego przekształcenia gospodarki rolnej, rolą FO było wyjaśnianie i popularyzacja wśród mieszkańców wsi zalet pracy w kolektywie i nakłanianie zapisywania się do kolektywnych gospodarstw rolnych. Działalność organizacyjna, polityczna i szkoleniowa organizacji okręgowych w celu osiągnięcia rezultatów oczekiwanych przez PMR była koordynowana centralnie przez KC FO. Wysiłek propagandowy i organizacyjny organizacji okręgowych Frontu miał koncentrować się nie tylko na przedstawianiu zalet kolektywizacji, ale również służyć „odgradzaniu” i „demaskowaniu” kułaków, tak by ich „odizolować od mas i wyrazić nienawiść pracującego chłopstwa wobec wroga klasowego"41.

Działania propagandowe, „popularyzacja”, „wyjaśnianie” polegały głównie na następujących czynnościach: „przerabianiu” artykułów z gazet „Scânteia” i „Frontul Plugarilor”, jak również broszur na temat socjalistycznej transformacji gospodarki rolnej, wydawanych przez Komitety Centralne PMR i FO; organizowaniu wizyt grup złożonych z członków

${ }^{40}$ D. Cătănuș, O. Roske, Colectivizarea agriculturii în România. Dimensiunea politică, vol. 1: 1949-1953, București 2000, s. 13.

${ }^{41}$ ANIC, Arhiva CC al PCR, fond Frontul Plugarilor, rola 432, cadrele 1-9. 
Frontu w kolektywnych gospodarstwach rolnych; organizowaniu ,spotkań kół czytelniczych”, a także szerzeniu propagandy „od człowieka do człowieka" pomiędzy członkami FO. Osoby odpowiedzialne za organizację kół czytelniczych miały być szkolone indywidualnie lub kolektywnie, $\mathrm{w}$ ramach rejonowych spotkań aktywistów oraz członków kolektywów szkoleniowych z kilku rejonów, w celu uświadomienia członków FO o ważkości całej kampanii. Co więcej, członkowie partii mieli być „wytrenowani w demaskowaniu wszelkich wrogich knowań kułaków, którzy będą próbowali sabotować uskutecznienie kampanii siewnej", czyli, innymi słowy, mieli donosić na tych, których podejrzewali o sprzeciwianie się kolektywizacji ${ }^{42}$.

Spośród wszystkich instrumentów propagandowych szczególną rolę odgrywały broszury na temat socjalistycznej transformacji gospodarki rolnej według modelu radzieckiego. Były one redagowane przez FO oraz PMR i potem dystrybuowane wśród rolników i „przerabiane” na spotkaniach kół i grup czytelniczych. Przykładowo w roku 1950 nakład tych broszur przekroczył milion egzemplarzy ${ }^{43}$. Ważną rolę w tym okresie odgrywała także gazeta „Frontul Plugarilor”, w której publikowano materiały związane z takimi zagadnieniami, jak zasiew, orka jesienna, zbiory, ocena plonów, spółdzielnie, gospodarstwa kolektywne, „walka o pokój” itp. Jeszcze inną metodą propagandową była praktyka zapraszania na spotkania organizacji sołeckich delegatów i „przodowników z kolektywów”, którzy odbyli wizyty w Związku Radzieckim i opowiadali członkom o ,zaletach pracy w kolektywie". Przykładowo, jedynie w pierwszym kwartale roku $1952 \mathrm{w}$ tę działalność było zaangażowanych około 3 tys. członków FO z 12 regionów. Liderzy formacji podkreślali natychmiastowe, pozytywne efekty tych metod propagandowych: „W organizacjach, do których zostali zaproszeni przodownicy kolektywizacji i delegaci po wizytach w ZSRR, atmosfera wokół GAC poprawiała się, a liczba wniosków o utworzenie GAC wzrosła" ${ }^{44}$.

Jednak mimo sporego wysiłku organizacyjnego przywódców FO aktywność tej formacji w tym zakresie w latach 1949-1951 była oceniana przez

42 „antrenați în a demasca toate uneltirile dușmănoase ale chiaburilor care vor încerca să saboteze îndeplinirea campaniei de însămânțări”, Dare de seamă de la 1 la 31 august 1950 de felul cum organizațiile Frontului Plugarilor au sprijinit munca de colectivizare a agriculturii, septembrie 1950, ANIC, Arhiva CC al PCR, fond Frontul Plugarilor, rola 433, cadrele 528-533; Comitetul Central. Secția de Educație - Plan de muncă pentru desfășurarea muncii de educație în Campania însămânțărilor, 6 martie 1952 , rola 438, cadrele 525-526.

${ }^{43}$ ANIC, Arhiva CC al PCR, fond Frontul Plugarilor, rola 435, cadrele 112-139.

44 „În organizațiile în care au fost invitați colectiviști fruntași și delegați ce au vizitat URSS, atmosfera în jurul GAC s-a îmbunătățit și numărul cererilor pentru GAC a crescut", Dare de seamă a Comitetului Central al Frontului Plugarilor pe perioada 1 ianuarie-31 martie 1952, 31 martie 1952, ibidem. 
samo kierownictwo jako „generalnie słaba”" ${ }^{4}$. Analiza sprawozdań Sekretariatu KC FO, Sekcji Edukacji i Propagandy, raportów z działalności sporządzonych przez organizacje okręgowe wykazuje szereg nieprawidłowości w zorganizowanych działaniach propagandowych. Jeśli nawet na poziomie centralnym propaganda wydawała się dobrze zorganizowana, to w terenie pojawiały się często poważne problemy w przekazywaniu treści propagandowych, przeważnie z powodu braku zaangażowania i inicjatywy kierowników organizacji okręgowych, gminnych i sołeckich, wykorzystywaniu nieprzygotowanych kadr, ludzi, którzy częstokroć sami nie rozumieli ani treści, które mieli przekazywać, ani celowości swoich działań ${ }^{46}$.

Generalnie rzecz ujmując, winę za wszelkie trudności, błędy i niezdolność organizacji okręgowych do przyciągnięcia większej liczby rolników do kolektywnych gospodarstw zrzucano na kułaków lub inny „nieodpowiedni element", który przeniknąwszy do lokalnych struktur kierowniczych, sabotował działalność Frontu. W ocenie kierownictwa Frontu w 1949 r. „nie wszędzie duch czujności był dość rozwinięty w odkrywaniu wrogich struktur, a wręcz podążano linią ugodową" ${ }^{47}$.

Mimo niedoskonałości, dzięki intensywnemu zaangażowaniu władz komunistycznych do 15 sierpnia 1950 utworzono - zgodnie z szacunkami Sekretariatu KC FO - 1845 kolektywnych gospodarstw rolnych. By zaś ocenić rolę Frontu w tym procesie, należy zaznaczyć, że spośród przeszło 49 tys. członków gospodarstw kolektywnych ponad 17 tys. było członkami FO. Porównując to jednak z całkowitą liczbą deklarowanych członków Frontu (ok. 1,4 mln), odsetek tych, którzy zdecydowali się zapisać do GAC, był wyjątkowo niski ${ }^{48}$.

Front, podobnie zresztą jak i partia komunistyczna, często poszukiwał „winnych" wszelkich niedociągnięć na zewnątrz formacji, a nie wśród swych członków. O ile w latach 1949-1950 za błędy i nieskuteczność kampanii propagandowej na rzecz socjalistycznego przekształcenia gospodarski rolnej mieli być odpowiedzialni kułacy, którzy przeniknęli do organów kierowniczych lokalnych komórek Frontu, o tyle w latach 1951-1952 „wina” została przypisana „elementom prawicowo odchylonym” w Rumuńskiej Partii Robotniczej, które rzekomo sabotowały organizację kolektywnych gospodarstw.

${ }^{45}$ ANIC, Arhiva CC al PCR, fond Frontul Plugarilor, rola 438, cadrele 534-539.

${ }^{46}$ ANIC, Arhiva CC al PCR, fond Frontul Plugarilor, rola 432, cadrele 71-79.

47 „nu peste tot însă spiritul de vigilență a fost destul de desvoltat în descoperirea elementelor dușmănoase, mergându-se chiar pe o linie împăciuitoristă”, Situația muncii Frontului Plugarilor pe anul 1949, decembrie 1949, ibidem.

${ }^{48}$ ANIC, Arhiva CC al PCR, fond Frontul Plugarilor, rola 433, cadrele 528-533. 
W procesie socjalistycznej transformacji gospodarki rolnej udział FO był fundamentalny. Działalność tej partii polegała przede wszystkim na propagandzie, prowadzonej w sposób zorganizowany i intensywny, przy użyciu sprawdzonych środków. Mimo tego i pomimo dużej liczby członków i zadeklarowanych sympatyków wyniki działalności propagandowej Frontu w przekonywaniu rolników do zalet rolnictwa kolektywnego nie były imponujące. Po marcu 1949 r. FO ewoluował w ścisłym związku z procesem przekształcania rolnictwa. Partia ta była całkowicie podporządkowana komunistom, którzy w sposób absolutny kontrolowali propagandę w środowiskach wiejskich. A ponieważ metody propagandowe nie przynosiły oczekiwanych rezultatów, w późniejszym okresie ich rola osłabła, podstawowymi zaś metodami „przekonywania” rolników stały się przymus państwowy i zinstytucjonalizowana przemoc, które w końcu dały rezultat pożądany przez komunistów - całkowitą kolektywizację rolnictwa.

\section{Wspieranie administracji komunistycznej (Rady Ludowe)}

Po 23 sierpnia 1944 r. Front Oraczy odegrał istotną rolę w procesie wymiany kadr urzędniczych w administracji, odziedziczonej po wojskowej dyktaturze Antonescu. Liczne sprawozdania sporządzone przez Okręgowe Inspektoraty Żandarmerii oraz Generalny Inspektorat Żandarmerii zawierają obszerne i ważne dane na temat tego procesu i na temat nadużyć, których dopuszczali się komuniści i ich „towarzysze drogi”, wspomagani bezpośrednio przez radzieckich okupantów. Żandarmi, ale nie tylko oni, regularnie donosili o niezadowoleniu ludności gmin i sołectw z powodu powoływania na stanowiska merów ludzi nieprzygotowanych, niekompetentnych i oportunistów. Duży odsetek merów i prefektów powołanych w taki sposób stanowili członkowie $\mathrm{FO}^{49}$. Sytuację tę odnotował także amerykański dziennikarz Reuben H. Markham, który oszacował, że pod koniec roku 1945 komuniści, poprzez FO, opanowali władzę niemal we wszystkich gminach wiejskich ${ }^{50}$.

Wraz z proklamowaniem Rumuńskiej Republiki Ludowej (30 XII 1947) i po przyjęciu pierwszej, wzorowanej na radzieckiej konstytucji (13 IV 1948) w Rumunii stworzono nowy typ administracji, w której władza lokalna została powierzona Radom Ludowym ${ }^{51}$. Groza, prezes FO, zo-

${ }^{49}$ D. Șandru, Comunizarea societății românești, s. 24-25.

${ }^{50}$ R.H. Markham, România sub jugul sovietic, București 1996 (oryg. ang. 1949), s. $270-271$.

51 Terytorium Rumunii było podzielone administracyjnie na gminy (comune), powiaty (plăși), okręgi (județe) i regiony (regiuni); miejscowymi organami władzy pań- 
stał ponownie prezesem Rady Ministrów. Pozostał na tym stanowisku do 2 czerwca 1952 r., kiedy to został wybrany przewodniczącym Prezydium Wielkiego Zgromadzenia Narodowego Rumuńskiej Republiki Ludowej - formalnie szefem państwa. Sprawował tę funkcję do śmierci 7 stycznia $1958 \mathrm{r}$.

O ile Grozie przyświecała nadal dobra gwiazda, szczęśliwe dni FO miały się ku końcowi. Wraz z konsolidacją władzy komunistów partia oraczy, w widoczny sposób zaniedbywana przez jej prezesa, schodziła na margines i stała się „przystawką” Rumuńskiej Partii Robotniczej w środowiskach wiejskich. Komuniści powierzyli jej zadanie wspierania Rad Ludowych, wyznaczania kandydatów do wyborów w tych jednostkach administracyjnych, które wobec braku jakiejkolwiek opozycji były jedynie formalnością: „Prezesi organizacji gminnych i sołeckich mają wykazać się pracą u podstaw, by ich gminy rozkwitały i by kwitła Rumuńska Republika Ludowa. Należy wspierać wszelkimi środkami Rady Ludowe we wszystkich ich przedsięwzięciach, a także wspierać wybory deputowanych do Rad Ludowych"52.

W ten sposób propagandziści FO mieli odegrać ważną rolę po raz ostatni: tym razem w przygotowaniu wyborów deputowanych do Rad Ludowych w grudniu 1950 r. Z okazji tych wyborów aktywiści otrzymali zadanie „przerobienia” $\mathrm{z}$ wyborcami różnorakich materiałów propagandowych, by ułatwić im zrozumienie kwestii związanych z budową socjalizmu w Rumunii, socjalistycznej transformacji rolnictwa, bratniej pomocy Związku Radzieckiego, wiodącej roli PMR itp..$^{53} \mathrm{~W}$ dystrybucji znalazły się materiały propagandowe KC FO, na przykład broszury na temat planu elektryfikacji, Watykanu, rejonizacji Rumuńskiej Republiki Ludowej, ustawy o Radach Ludowych, raportu Gheorge Gheorghiu-Deja na temat elektryfikacji RRL, techniki głosowania i inne ${ }^{54}$.

stwowej były lokalne rady ludowe, wybierane w wyborach na okres 4 lat. Nowa konstytucja wprowadzała pojęcie „regionów” i „rad ludowych” (które zastąpiły „rady” z poprzednich konstytucji), tworząc nową siatkę organizacji administracyjnej i wprowadzając władzę „rad” (od ros. sowiet) na poziomie lokalnym (E. Focșeneanu, Istoria constituțională a României 1859-1991, București 1992, s. 110-113; România 1945-1989. Enciclopedia regimului comunist. Instituții de partid, de stat, obștești și cooperatiste, red. D. Cătănuș, București 2012, s. 206-211).

52 „Președinți organizațiilor comunale și sătești vor trebui să depună o muncă temeinică pentru înflorirea comunei și a Republicii Populare România. Să dea tot sprijinul Sfaturilor Populare în orice acțiune vor întreprinde, la fel să sprijine alegerile de deputați în Sfaturile Populare", Proces-verbal încheiat în ziua de 8 octombrie cu ocazia instalării activului de raion Alba, 8 octombrie 1950, SJHANR, fond Comitetul Regional PCR Hunedoara, dos. 83/1950, f. 192.

${ }^{53}$ SJHANR, fond Comitetul Regional PCR Hunedoara, dos. 83/1950, f. 253, 254.

${ }^{54}$ Ibidem, f. 262, 263. 
Liderzy FO byli przeświadczeni o ważnej roli popierania działalności Rad Ludowych i wierzyli, że w Rumunii socjalizm nie może zostać zbudowany bez aktywnego udziału milionów ludzi pracy z miast i wsi.

Rady ludowe, będące najszerszą formą organizacji ludu pracującego, są jednym ze środków, za pomocą których partia mobilizuje masy do dzieła budowy socjalizmu. Pod przewodnictwem organizacji partyjnych organizacje Frontu Oraczy wsparły Rady Ludowe w mobilizowaniu ludu pracującego wsi, w celu zrealizowania zadań wyznaczonych przez partię na wsi ${ }^{55}$.

Na poziomie lokalnym jednak, liczne raporty i sprawozdania sporządzane przez aktywistów partyjnych wysłanych na kontrolę w latach 19511952 wykazują, że w organizacjach terytorialnych Frontu panował marazm, brak zaangażowania, członkowie partii zaś „nie wspierają w dostatecznym stopniu działalności Rad Ludowych" ${ }^{56}$. Najczęściej wymienianymi nieprawidłowościami w relacjach między Frontem i Radami Ludowymi były: absencja deputowanych FO na posiedzeniach i akcjach Rad Ludowych; nierealizowanie zadań przewidzianych w planach; ,tendencja do odgradzania się od rad ludowych, przez niewiązanie działalności członków z zadaniami rad ludowych"; niektórzy deputowani członkowie FO „nie byli kierowani i aktywizowani do pracy w komisjach stałych rady ludowej”; odnotowane były przypadki, w których „przez brak kierownictwa ze strony organizacji część deputowanych - członków Fr. Oraczy wykazywała wrogą postawę wobec niektórych środków stosowanych przez partię i rząd"; przenikanie do Rad Ludowych elementów kułackich, które sabotowały ich działalność. W duchu samokrytyki kierownictwo centralne FO przyznawało się częściowo do winy za zaistniałą sytuację: „Odpowiedzialność za braki i niedociągnięcia wykazane w pracy organizacji Frontu Oraczy odnośnie do wsparcia, którego należy udzielać radom ludowym, spoczywa także na barkach Komitetu

55 „Sfaturile populare, ca cea mai largă organizație a poporului muncitor, sunt unul din mijloacele cu ajutorul cărora partidul mobilizează masele la opera de construire a socialismului. Sub conducerea și îndrumarea organizațiilor de partid, organizașiile Frontul Plugarilor au sprijinit Sfaturile Populare în mobilizarea țărănimii muncitoare pentru realizarea sarcinilor puse de partid și guvern la sate", Comitetul Central. Instrucțiuni privind intensificarea muncii organizațiilor Frontului Plugarilor în sprijinul Sfaturilor Populare, 27 mai 1952, ANIC, Arhiva CC al PCR, fond Frontul Plugarilor, rola 435, cadrul 210.

56 „ne-mai sprijinind suficient activitatea Sfaturilor Populare”, Șandru Romulus Raport asupra muncii din regiunea Hunedoara în timpul celor două zile, 12 și 13 martie 1952, 19 martie 1952, ANIC, Arhiva CC al PCR, fond Frontul Plugarilor, rola 439, cadrul 21-23. 
Centralnego Frontu Oraczy, który nie pogłębił i nie wskazał na czas, na podstawie szczegółowej kontroli, nowych form i metod dla wzmocnienia wsparcia, którego organizacje Frontu Oraczy winny udzielać Radom Ludowym" 57 .

\section{Koniec ostatniego "towarzysza drogi”}

Koniec roku 1952 i początek 1953 charakteryzują nowe metody mające za zadanie konsolidację „władzy ludowej”, przyśpieszenie tempa przemian politycznych i gospodarczych, umacniających system jednopartyjny. W tych warunkach zbędne już stało się istnienie innej formacji politycznej o tym samym profilu ideologicznym i stosującej identyczne praktyki polityczne. W miarę poszerzania wpływów politycznych PMR w środowiskach wiejskich za pomocą coraz to wydajniejszych struktur w rodzaju Rad Ludowych, rola i obowiązki Frontu Oraczy topniały. Sprawy stały się całkowicie jasne w momencie uchwalenia nowej konstytucji z 24 września 1952 r. Znalazł się w niej zapis o tym, że Rumuńska Partia Robotnicza jest „przewodnią siłą zarówno wszystkich organizacji ludzi pracy,jak również organów i instytucji państwa" ${ }^{58}$. W tym kontekście stało się jasne, że FO został organizacją-wydmuszką, mimo że Groza pełnił jeszcze ważne funkcje państwowe. Fala zmian zainicjowana przez G. Gheorghiu-Deja w latach 1952-1953 dotknęła także FO, ostatniego reliktu pluralizmu politycznego. Podczas posiedzenia 7 lutego 1953 r. KC FO postanowił o zakończeniu swojej działalności i samorozwiązaniu wszystkich organów i organizacji w środowiskach wiejskich, stwierdzając, że „,jego dalsze istnienie nie jest już konieczne, ponieważ prowadziłoby do rozdrobnienia aktywnych sił wiejskich mas pracujących” ${ }^{9}$. „Uczciwy i aktywny element” spośród

57 ,tendința de a se izola de sfaturile populare, nelegând activitatea membrilor cu sarcinile sfaturilor populare”; „n-au fost îndrumați și activizați de a munci în comisiile permanente ale sfatului popular”; „datorită lipsei de îndrumare din partea organizației, o parte din deputați - membri ai Fr. Plugarilor - s-au manifestat dușmănos față de unele măsuri luate de partid și guvern”; „Răspunderea asupra lipsurilor manifestate în munca organizațiilor Fr. Plugarilor privind sprijinul ce trebuie dat sfaturilor populare, revine și Comitetul Central al Frontului Plugarilor care nu a adâncit și nu a indicat la timp, pe baza unui control amănunțit, forme și metode noi pentru întărirea sprijinului ce trebuie dat de organizațiile Frontului Plugarilor Sfaturilor Populare", Comitetul Central. Instrucțiuni privind intensificarea muncii organizațiilor Frontului Plugarilor în sprijinul Sfaturilor Populare, 27 mai 1952, ANIC, Arhiva CC al PCR, fond Frontul Plugarilor, rola 435, cadrele $210-213$.

58 „forța conducătoare atât a organizațiilor celor ce muncesc, cât și a organelor și instituțiilor de stat”, E. Focșeneanu, op. cit., s. 115.

59 „existența sa pe mai departe nu mai este necesară, deoarece ar duce la fărămițarea forțelor active ale țărănimii muncitoare”, Hotărârea Comitetului Central al 
organizacji Frontu został zaangażowany do pracy w radach ludowych, spółdzielniach i domach kultury. Członkowie KC FO, jak również liderzy na poziomie regionalnym zajęli stanowiska w różnorakich strukturach PMR. Środki trwałe należące do organizacji FO w regionach i rejonach zostały przekazane organizacjom PMR ${ }^{60}$.

Likwidacja FO wywołała sprzeczne reakcje wśród rolników. Z jednej strony „samorozwiązanie” klarowało ewidentną sytuację nakładania się działalności Frontu z aktywnością PMR, z drugiej strony zaś spowodowało dezorientację. Świadczą o tym odnotowane wówczas pogłoski, jakoby wkrótce miała wybuchnąć wojna lub, co jeszcze bardziej interesujące, że FO został rozwiązany, ponieważ „tow. Groza” uciekł z kraju ${ }^{61}$.

Zjęz. ang. tłumaczył Tomasz Kluz

\section{The Political Organisation of the Peasantry in Communist Romania: The Ploughmen's Front (1945-1953)}

This article comes to fill a period from the Romanian history that remained not enough explained: the process of communization and the role played by the comrade of the Communist Party. The Ploughmen's Front represented the strongest and the oldest comrade of the Communist Party from Romania. The main task of Ploughmen's Front was to implement the Communist ideology in the countryside, facilitating the process of communization of the Romanian villages, where the Communists were extremely unpopular. The article focuses on the structures of the ploughmen's organization, and especially the manner in which the Ploughmen's Front was involved in the communization of the Romanian countryside. The research work is based on unpublished archival documents as well as on the assessment of Romanian and foreign historiography and on the propaganda materials used by the Ploughmen's Front. In 1949-1953 the Ploughmen's Front had organizations in almost all the villages and communes of Romania and its main task was to spread the ideas of the Communist party among peasants, especially those regarding the socialist transformation, the importance of the party in the peasant life and modernization of the village.

Frontului Plugarilor privind încetarea activității sale și autodizolvarea tuturor organizațiilor Frontul Plugarilor, 7 februarie 1953, ANIC, Arhiva CC al PCR, fond Frontul Plugarilor, rola 439, cadrele 1062.

${ }^{60}$ N. Georgescu, S. Radu „Autodizolvarea” Frontului Plugarilor (1953), „Apulum”, vol. 46, 2009, s. 211-231.

${ }^{61}$ SJTANR, fond Comitetul Regional Timișoara Organizația Frontul Plugarilor, dos. 38/1953, f. 45. 